\title{
Polydentate Schiff Base Ligands and Their La(III) Complexes: Synthesis, Characterization, Antibacterial, Thermal, and Electrochemical Properties
}

\author{
Ali E. Şabik,, ${ }^{1}$ Muharrem Karabörk,, ${ }^{2}$ Gökhan Ceyhan, ${ }^{2}$ Mehmet Tümer,, ${ }^{2}$ and Metin Diğrak ${ }^{3}$ \\ ${ }^{1}$ Chemistry Department, Osmaniye Korkut Ata University, 80100 Osmaniye, Turkey \\ ${ }^{2}$ Chemistry Department, K.Maras Sütcü Imam University, 46100 K.Maras, Turkey \\ ${ }^{3}$ Biology Department, K.Maras Sütcü Imam University, 46100 K.Maras, Turkey
}

Correspondence should be addressed to Mehmet Tümer, mtumer@ksu.edu.tr

Received 3 November 2011; Revised 27 December 2011; Accepted 14 January 2012

Academic Editor: Maurizio Peruzzini

Copyright ( 2012 Ali E. Şabik et al. This is an open access article distributed under the Creative Commons Attribution License, which permits unrestricted use, distribution, and reproduction in any medium, provided the original work is properly cited.

\begin{abstract}
We synthesized the Schiff base ligands $\mathrm{H}_{2} \mathrm{~L}^{1}-\mathrm{H}_{2} \mathrm{~L}^{4}$ and their $\mathrm{La}(\mathrm{III})$ complexes and characterized them by the analytical and spectroscopic methods. We investigated their electrochemical and antimicrobial activity properties. The electrochemical properties of the ligands $\mathrm{H}_{2} \mathrm{~L}^{1}-\mathrm{H}_{2} \mathrm{~L}^{4}$ and their $\mathrm{La}$ (III) complexes were studied at the different scan rates (100 and $200 \mathrm{mV}$ ), different $\mathrm{pH}$ ranges $(\mathrm{pH}=2-12)$, and in the different solvents. The electrooxidation of the Schiff base ligands involves a reversible transfer of two electrons and two protons in solutions of $\mathrm{pH}$ up to 5.5, in agreement with the one-step two-electron mechanism. In solutions of $\mathrm{pH}$ higher than 5.5, the process of electrooxidation reaction of the Schiff base ligands and their La(III) complexes follows an ECi mechanism. The antimicrobial activities of the ligands and their complexes were studied. The thermal properties of the metal complexes were studied under nitrogen atmosphere in the range of temperature $20-1000^{\circ} \mathrm{C}$.
\end{abstract}

\section{Introduction}

Schiff bases were firstly synthesized by H. Schiff. Condensation of primary amines with carbonyl compounds yields Schiff bases [1,2]. Schiff bases have been amongst the most widely studied coordination compounds and are becoming increasingly important as biochemical, analytical, and antimicrobial reagents [3]. Schiff bases derived from a large number of carbonyl compounds and amines have been used $[4,5]$. The transition metal complexes having oxygen and nitrogen donor Schiff bases possess unusual configuration, structural liability, and are sensitive to the molecular environment [6]. Lanthanides or lanthanos form a largest series of periodic table. It is $4 \mathrm{f}$ inner transition series. Lanthanide (III) ions, because of their size, are the best ions form stable complexes with high coordination number $[7,8]$. The number of Schiff base complexes of the lanthanide elements is similarly limited to a few reports [9].

A large number of compounds of the type $\mathrm{M}\left(\mathrm{N}_{2} \mathrm{O}_{2}\right)$, $\mathrm{M}\left(\mathrm{N}_{2} \mathrm{~S}_{2}\right), \mathrm{M}\left(\mathrm{N}_{2}\right)$, and $\mathrm{M}\left(\mathrm{N}_{4}\right)$ (using the binding atom representation) have been synthesized and characterized. These type complexes have been investigated because of their catalytic activity in oxygenation reactions [10], carrying out, for instance, the selective oxidation of organic substrates, such as olefins, alcohols, alkanes, and aldehydes, under mild conditions. This property may be very attractive [11], since the oxidation products can provide important starting materials for the production of fine chemicals and polymers [12, 13]. In addition, the oxidation of organic substrates mediated by high valent ruthenium oxo species evokes much interest in the modeling of cytochrome P-450 [14]. Several researches have proposed that the redox potential in Schiff base complexes is directly related to many of the biologically relevant chemical characteristics of the entire complex, for example, dioxygen binding ability and nucleophilicity [15]. Thus, there has been a strong interest in determining thermodynamically meaningful redox potentials of copper Schiff base complexes and in understanding the relationship between these potentials and the detailed structure of the Schiff base ligand [16]. Numerous electrochemical studies have been 
made for a fairly large number of acyclic and macrocyclic copper (II) complexes derived from Schiff bases. These investigations revealed that the redox properties of copper (II) complexes are markedly influenced by structural and electronic factors [17].

In this study, we synthesized four Schiff base ligands and their La(III) complexes and characterized by the analytical and spectroscopic methods. The ligands and their metal complexes show the reversible, quasireversible, and irreversible electrochemical processes. The Schiff base ligands and their $\mathrm{La}(\mathrm{III})$ complexes have the antimicrobial activity.

\section{Experimental}

2.1. Reagents and Materials. All chemicals used in this study were obtained commercially and used without purification. The metal salt $\mathrm{La}\left(\mathrm{NO}_{3}\right)_{3} \cdot 6 \mathrm{H}_{2} \mathrm{O}$ and organic solvents were purchased from commercial sources and used as received, unless noted otherwise. 2,4-Diaminobenzene sulphonic acid, 2,5-diaminobenzene sulphonic acid, 3,5-diaminobenzoic acid, 2,4-dihydroxybenzaldehyde, and 2-hydroxy-3methoxybenzaldehyde and $\left(\left[\mathrm{CH}_{3}\left(\mathrm{CH}_{2}\right)_{3}\right]_{4} \mathrm{NBF}_{4}\right)$ were obtained from Fluka.

2.2. Physical Measurements. Elemental analyses $(\mathrm{C}, \mathrm{H}, \mathrm{N})$ were performed using a LECO CHNS 932. Infrared spectra were obtained using $\mathrm{KBr}$ dics $\left(4000-400 \mathrm{~cm}^{-1}\right)$ on a Perkin Elmer Spectrum 100 FT-IR. Far spectra of the complexes were recorded on a Perkin Elmer spectrum 400 FT-IR/FTFAR. The electronic spectra in the $200-900 \mathrm{~nm}$ range were obtained on a Perkin Elmer Lambda 45 spectrophotometer. Molar conductivities of the Schiff base ligands and their transition metal complexes were determined in $\operatorname{DMF}\left(\sim 10^{-3} \mathrm{M}\right)$ at room temperature using a Jenway Model 4070 conductivity meter. Mass spectra of the ligands were recorded on a LC/MS APCI AGILENT 1100 MSD mass spectrophotometer. ${ }^{1} \mathrm{H}$ and ${ }^{13} \mathrm{C}$ NMR spectra were taken on a Varian XL 200 NMR instrument. TMS was used as internal standart deuterated dimethyl sulfoxide as solvent.

Cyclic voltammograms were recorded on an Iviumstat Electrochemical workstation equipped with a low current module (BAS PA-1) recorder. The electrochemical cell was equipped with a BAS glassy carbon working electrode (area $4.6 \mathrm{~mm}^{2}$ ), a platinum coil auxiliary electrode, and an $\mathrm{Ag}^{+} /$ $\mathrm{AgCl}$ reference electrode filled with tetrabutylammonium tetrafluoroborate $(0.1 \mathrm{M})$ in DMSO and DMF solvents and adjusted to $0.00 \mathrm{~V}$ versus SCE. Cyclic voltammetric measurements were made at room temperature in an undivided cell (BAS model C-3 cell stand) with a platinum counterelectrode and an $\mathrm{Ag}^{+} / \mathrm{AgCl}$ reference electrode (BAS). All potentials are reported with respect to $\mathrm{Ag}^{+} / \mathrm{AgCl}$. The solutions were deoxygenated by bubbling dry nitrogen through the solution for $30 \mathrm{~min}$ prior to the experiments, and, during the experiments, the flow was maintained over the solution. Digital simulations were performed using DigiSim 3.0 for windows (BAS, Inc.). Experimental cyclic voltammograms used for the fitting process had the background subtracted and were corrected electronically for ohmic drop.
2.3. Preparation of Schiff Base Ligands $\left(\mathrm{H}_{2} L^{1}-\mathrm{H}_{2} L^{4}\right)$. All the Schiff base ligands were prepared according to the fallowing method. The amine derivatives (2,4-diaminobenzene sulphonic acid (1 mmol) to prepare $\mathrm{H}_{2} \mathrm{~L}^{1}$ and $\mathrm{H}_{2} \mathrm{~L}^{3}$; 3,5-diaminobenzoic acid $(1 \mathrm{mmol})$ to prepare $\mathrm{HL}^{2} ; 2,5-$ diaminobenzenesulfonic acid ( $1 \mathrm{mmol}$ ) to prepare $\mathrm{H}_{2} \mathrm{~L}^{4}$ ) in the EtOH solution $(50 \mathrm{~mL})$ were mixed and then added to the carbonyl compounds (o-vanillin $(2 \mathrm{mmol})$ to prepare $\mathrm{H}_{2} \mathrm{~L}^{1}$, $\mathrm{H}_{2} \mathrm{~L}^{2}$, and $\mathrm{H}_{2} \mathrm{~L}^{4} ;$ 2,4-dihydroxybenzaldehyde $(2 \mathrm{mmol}$ ) to prepare $\mathrm{H}_{2} \mathrm{~L}^{3}$ ) and refluxed for $12 \mathrm{~h}$ at $80^{\circ} \mathrm{C}$. After the reaction mixture was allowed to cool to room temperature, the solvent was evaporated and the solid residue was recrystallized from $\mathrm{EtOH}$ and dried under vacuum desiccator.

2.4. Preparation of Schiff Base Complexes. To solution of Schiff base ligand $\left(\mathrm{H}_{2} \mathrm{~L}^{1}-\mathrm{H}_{2} \mathrm{~L}^{4}\right)(1 \mathrm{mmol})$ dissolved in absolute $\mathrm{EtOH}(20 \mathrm{~mL})$ was added a solution of $\left[\mathrm{La}\left(\mathrm{NO}_{3}\right)_{3} \cdot 6 \mathrm{H}_{2} \mathrm{O}\right](1 \mathrm{mmol})$ in the EtOH $(20 \mathrm{~mL})[2: 1$ molar ratio $(\mathrm{M}: \mathrm{L})$ for $\mathrm{H}_{2} \mathrm{~L}^{1}, \mathrm{H}_{2} \mathrm{~L}^{3}$, and $\mathrm{H}_{2} \mathrm{~L}^{4}, 1: 1$ molar ratio $(\mathrm{M}: \mathrm{L})$ for $\mathrm{H}_{2} \mathrm{~L}^{2}$ ] was added. The mixture was stirred for 20 hours at $80^{\circ} \mathrm{C}$. The final complex precipitated out from the solution was filtered off, washed with cold ethanol, and dried in a vacuum desiccator.

\section{Preparation of Microbial Culture}

The Schiff base ligands and their metal complexes were evaluated for their in vitro antibacterial activity against the B. megaterium, B. cereus, S. aureus, M. luteus, and E. faecalis (as Gram-positive bacteria) and P. aeruginosa, E. coli, and C. albicans (as Gram-negative bacteria) by agar-well diffusion. Bacterium was inoculated into nutrient broth (Difco), incubated for $24 \mathrm{~h}$ and the fungi studied inoculated in malt extract broth (Difco) for $48 \mathrm{~h}$. In the agar-well diffusion method, Mueller Hinton Agar (Oxoid) for bacterium and in Malt Extract Broth (Difco) sterilized in a flask, cooled to 45$50^{\circ} \mathrm{C}$, and were distributed $(20 \mathrm{~mL})$ to sterilized petri dishes after injecting $0.01 \mathrm{~mL}$ cultures of bacterium prepared as mentioned above and allowed to solidify. The dilution plate method was used to enumerate microorganisms $\left(10^{5}\right.$ bacterium $\left.\mathrm{mL}^{-1}\right)$ and fungi $\left(10^{3}-10^{4} \mathrm{~mL}^{-1}\right)$ for $24 \mathrm{~h}$ [18]. By using a sterilized cork borer ( $7 \mathrm{~mm}$ diameter), wells were dug in the culture plates. Compounds dissolved in DMSO were added $(0.2 \mathrm{~mL})$ to these wells. The petri dishes were left at $4^{\circ} \mathrm{C}$ for $2 \mathrm{~h}$, and then the plates were incubated at $30^{\circ} \mathrm{C}$ for bacterium $(18-24 \mathrm{~h})$ and at $25^{\circ} \mathrm{C}$ for fungi $(72 \mathrm{~h})$. At the end of the period, inhibition zones formed on the medium were evaluated as millimeters $(\mathrm{mm})$. The control samples were only absorbed in DMSO. Blank tests showed that DMSO solvent did not affect the antimicrobial activity of the compounds.

\section{Results and Discussion}

In this study, the ligands $\mathrm{N}, \mathrm{N}^{\prime}$-bis[(3-metoxysalicylidene)]2,4-diaminobenzene sulphonic acid $\left(\mathrm{H}_{2} \mathrm{~L}^{1}\right), \mathrm{N}, \mathrm{N}^{\prime}$-bis [ $(3-$ metoxysalicylidene)]-3,5-diaminobenzene carbonic acid 
TABLE 1: Some analytical and physical data for the imine ligands and their complexes.

\begin{tabular}{|c|c|c|c|c|c|c|}
\hline \multirow{2}{*}{ Compound } & \multirow{2}{*}{ Color } & \multirow[t]{2}{*}{ Yield (\%) } & \multirow[t]{2}{*}{ M.p. $\left({ }^{\circ} \mathrm{C}\right)$} & \multicolumn{3}{|c|}{ Found (Calcd) \% } \\
\hline & & & & $\mathrm{C}$ & $\mathrm{H}$ & $\mathrm{N}$ \\
\hline $\mathrm{H}_{2} \mathrm{~L}^{1}$ & Red & 74 & 99 & $57.92(57.89)$ & $4.45(4.42)$ & $6.17(6.14)$ \\
\hline $\mathrm{La}_{2}\left(\mathrm{~L}^{1}\right)\left(\mathrm{NO}_{3}\right)_{4}\left(\mathrm{H}_{2} \mathrm{O}\right)_{4}$ & Brown & 70 & $>250$ & $53.30(53.35)$ & $2.43(2.46)$ & $6.25(6.22)$ \\
\hline $\mathrm{H}_{2} \mathrm{~L}^{2}$ & Yellow & 78 & 250 & $65.50(65.70)$ & $4.83(4.79)$ & $6.63(6.66)$ \\
\hline $\mathrm{La}\left(\mathrm{L}^{2}\right)\left(\mathrm{NO}_{3}\right)\left(\mathrm{H}_{2} \mathrm{O}\right)$ & Dark brown & 67 & $>250$ & $43.30(43.34)$ & $3.20(3.16)$ & $6.56(6.59)$ \\
\hline $\mathrm{H}_{2} \mathrm{~L}^{3}$ & Light brown & 72 & 134 & $56.10(57.70)$ & $3.74(3.76)$ & $6.58(6.54)$ \\
\hline $\mathrm{La}_{2}\left(\mathrm{~L}^{3}\right)\left(\mathrm{NO}_{3}\right)_{4}\left(\mathrm{H}_{2} \mathrm{O}\right)_{4}$ & Black & 59 & $>250$ & $37.19(37.22)$ & $2.48(2.50)$ & $6.48(6.51)$ \\
\hline $\mathrm{H}_{2} \mathrm{~L}^{4}$ & Light brown & 68 & 250 & $57.92(57.89)$ & $4.45(4.42)$ & $6.10(6.14)$ \\
\hline $\mathrm{La}_{2}\left(\mathrm{~L}^{4}\right)\left(\mathrm{NO}_{3}\right)_{4}\left(\mathrm{H}_{2} \mathrm{O}\right)_{4}$ & Black & 60 & $>250$ & $25.14(25.11)$ & $2.52(2.49)$ & $8.03(7.99)$ \\
\hline
\end{tabular}<smiles>COc1cccc(/C=N/c2cc(/N=C/c3cccc(OC)c3O)cc(C(=O)O)c2)c1O</smiles>

$\mathrm{H}_{2} \mathrm{~L}^{1}$<smiles>[R4]c1ccc(/C=C/c2cc(/N=C/c3ccc([Y])c([Y])c3O)ccc2S(=O)(=O)O)c(O)c1[Y]</smiles>

$\mathrm{H}_{2} \mathrm{~L}^{2}$ and $\mathrm{H}_{2} \mathrm{~L}^{3}$<smiles>COc1cccc(/C=N/c2ccc(/N=C/c3cccc(OC)c3O)c(C(=O)O)c2)c1O</smiles>

$\mathrm{H}_{2} \mathrm{~L}^{4}$

Figure 1: Proposed structures of the Schiff base ligands. $\mathrm{R}^{1}$ is $\mathrm{OCH}_{3}$ and $\mathrm{R}^{2}$ is $\mathrm{H}$ for the ligand $\mathrm{H}_{2} \mathrm{~L}^{2}$, and $\mathrm{R}^{1}$ is $\mathrm{H}_{\text {and }} \mathrm{R}^{2}$ is $\mathrm{OH}$ for the ligand $\mathrm{H}_{2} \mathrm{~L}^{3}$.

$\left(\mathrm{H}_{2} \mathrm{~L}^{2}\right), \mathrm{N}, \mathrm{N}^{\prime}$-bis[(4-hidroxysalicylidene)]-2,4-diaminobenzene sulphonic acid $\left(\mathrm{H}_{2} \mathrm{~L}^{3}\right)$ N,N'-bis[(3-metoxysalicylidene)]-2,5-diaminobenzene sulphonic acid $\left(\mathrm{H}_{2} \mathrm{~L}^{4}\right)$ were synthesized and characterized by the analytical and spectroscopic methods. Condensation of the aldehydes with primary amines readily gives the corresponding imines, which were easily identified by their IR, ${ }^{1} \mathrm{H}$-, and ${ }^{13} \mathrm{C}$-NMR spectra. Replacement of the carbonyl by the imine results in (i) lowering of the energy of the $v(\mathrm{C}=\mathrm{O})$ stretch in the IR spectrum and (ii) a shift to higher field of the $\mathrm{CH}=\mathrm{N}$ proton signal in the ${ }^{1} \mathrm{H}$-NMR spectrums. The imines prepared in this way are formed in nearly quantitive yields and are of high purity. All compounds are stable at room temperature in the solid state. Analytical data and some physical properties of the Schiff base ligands and their metal complexes are given in Table 1.

All the ligands and their complexes are soluble in common organic solvents, such as $\mathrm{CHCl}_{3}, \mathrm{EtOH}, \mathrm{MeOH}, \mathrm{DMF}$, and DMSO because of $-\mathrm{OH},-\mathrm{CH}=\mathrm{N}-, \mathrm{SO}_{3} \mathrm{H}$, and $\mathrm{COOH}$ groups. The $-\mathrm{SO}_{3} \mathrm{H}$ and $-\mathrm{COOH}$ groups in the ligands provide great advantages of the solubility properties. These groups provide solubility also in the water. $\mathrm{La}$ (III) complexes of the ligands $\mathrm{H}_{2} \mathrm{~L}^{1}-\mathrm{H}_{2} \mathrm{~L}^{4}$ were synthesized and investigated by the some analytical and spectroscopic methods. A little water added secure solubility of the ligands when some problems occur at solubility. The proposed structures of the ligands were shown in Figure 1.

The infrared spectral data of the ligands $\left(\mathrm{H}_{2} \mathrm{~L}^{1}-\mathrm{H}_{2} \mathrm{~L}^{4}\right)$ and their metal complexes are given in Table 2. Ligands have carboxyl, azomethine, and phenolic $\mathrm{C}-\mathrm{OH}$ groups. In the infrared spectra of ligands $\mathrm{H}_{2} \mathrm{~L}^{1}$ and $\mathrm{H}_{2} \mathrm{~L}^{4}$, the strong vibration at 3402 and $3099 \mathrm{~cm}^{-1}$ can be attributed to the $v(\mathrm{O}-$ $\mathrm{H})$ group. In the complexes, these bands were shifted to the lower regions. For the free ligands, the board bands in the $2800-2700 \mathrm{~cm}^{-1}$ range are assigned to the $\mathrm{OH}$ group vibration (ortho position) associated intramolecularly with the nitrogen atom of the $\mathrm{CH}=\mathrm{N}$ group [19].

In the complexes, these bands disappear as a result of proton substitution by cation coordination to the oxygen atoms of the ligands. In the spectra of the ligands, the strong bands 
TABLE 2: Infrared, electronic spectral, and molar conductivities ${ }^{\mathrm{a}}$ data for the Schiff base ligands and their metal complexes $\left(\mathrm{cm}^{-1}\right)$.

\begin{tabular}{lcccccc}
\hline Compound & $v(-\mathrm{OH})$ & $v\left(\mathrm{CH}_{3}\right)$ & $\nu(\mathrm{CH}=\mathrm{N})$ & $\nu(\mathrm{C}-\mathrm{OH})$ & $\lambda_{\max }(\mathrm{nm})$ & ${ }^{\mathrm{a}} \Lambda$ \\
\hline $\mathrm{H}_{2} \mathrm{~L}^{1}$ & 3350 & 2941 & 1638 & 1326 & $305,345,405,420$ & 5.6 \\
$\mathrm{H}_{2} \mathrm{~L}^{2}$ & - & 2984 & 1613 & 1304 & $345,405,430,465$ \\
$\mathrm{H}_{2} \mathrm{~L}^{3}$ & 3099 & - & 1614 & 1324 & $305,405,430,465$ \\
$\mathrm{H}_{2} \mathrm{~L}^{4}$ & 3432 & - & 1659 & 1306 & $330,430,465$ & 5.9 \\
$\mathrm{La}_{2}\left(\mathrm{~L}^{1}\right)\left(\mathrm{NO}_{3}\right)_{4}\left(\mathrm{H}_{2} \mathrm{O}\right)_{4}$ & 3393 & 2950 & 1646 & 1291 & $315,345,405,430$ \\
$\mathrm{La}\left(\mathrm{L}^{2}\right)\left(\mathrm{NO}_{3}\right)\left(\mathrm{H}_{2} \mathrm{O}\right)$ & 3350 & 2989 & 1634 & 1296 & $345,405,420,465$ \\
$\mathrm{La}_{2}\left(\mathrm{~L}^{3}\right)\left(\mathrm{NO}_{3}\right)_{4}\left(\mathrm{H}_{2} \mathrm{O}\right)_{4}$ & 3334 & - & 1624 & 1287 & $305,405,430,465$ \\
$\mathrm{La}_{2}\left(\mathrm{~L}^{4}\right)\left(\mathrm{NO}_{3}\right)_{4}\left(\mathrm{H}_{2} \mathrm{O}\right)_{4}$ & 3361 & - & 1611 & 1306 & $305,345,405,430,465$ & 13.2 \\
\hline$\Omega^{-1}$ & & & & & 16.5 \\
\hline
\end{tabular}

${ }^{\mathrm{a}}: \Omega^{-1} \mathrm{~cm}^{2} \mathrm{~mol}^{-1}\left(25^{\circ} \mathrm{C}\right)$.

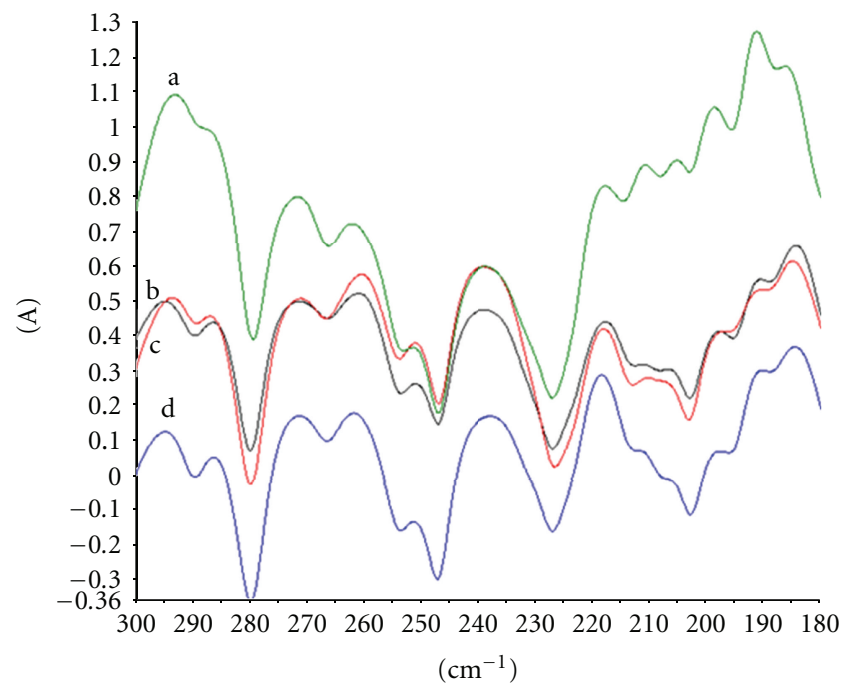

Figure 2: The Far spectra of the La(III) complexes of the Schiff base ligands. a: $\mathrm{La}_{2}\left(\mathrm{~L}^{4}\right)\left(\mathrm{NO}_{3}\right)_{4}\left(\mathrm{H}_{2} \mathrm{O}\right)_{4}, \mathrm{~b}: \mathrm{La}_{2}\left(\mathrm{~L}^{3}\right)\left(\mathrm{NO}_{3}\right)_{4}\left(\mathrm{H}_{2} \mathrm{O}\right)_{4}$, c: $\mathrm{La}_{2}\left(\mathrm{~L}^{1}\right)\left(\mathrm{NO}_{3}\right)_{4}\left(\mathrm{H}_{2} \mathrm{O}\right)_{4}$, and d: $\mathrm{La}\left(\mathrm{L}^{2}\right)\left(\mathrm{NO}_{3}\right)\left(\mathrm{H}_{2} \mathrm{O}\right)$.

observed in the $1659-1611 \mathrm{~cm}^{-1}$ range were assigned to the azomethine group vibration and its shift indicates that, in complexes, coordination of ligands in complexes is through azo methinic nitrogen atom. The bands assigned to benzene ring vibration compared well, with those of monosubstituted derivatives of benzene, several other modes associated with $\mathrm{C}-\mathrm{H}$ out of plane deformation appear in the region [764$754 \mathrm{~cm}^{-1}$ ]. Some new medium to weak bands were also observed in the range ( 496 to $470 \mathrm{~cm}^{-1}$ ) in case of complexes ligands have no absorption. These new medium to weak bands are assigned as $\nu(\mathrm{Ln}-\mathrm{N})$ modes observed for various lanthanide (III) nitrate complexes. Bands in the far infrared spectra, in the region $278-255 \mathrm{~cm}^{-1}$, can be assigned to $\nu(\mathrm{Ln}-\mathrm{N})$ vibration in the new complexes [20]. This situation was shown in Figure 2.

It has been found that the separation of $\left(\nu_{2}+\nu_{5}\right)$ and $\left(\nu_{2}+\right.$ $v_{3}$ ) is greater in bidentate (about $30-40 \mathrm{~cm}^{-1}$ ) than in monodentate (about $10 \mathrm{~cm}^{-1}$ ) nitrate complexes. The separation of $\left(\nu_{2}+v_{1}\right)$ and $\left(\nu_{2}+v_{4}\right)$ frequencies is greater for bidentate nitrate anions (about $80-100 \mathrm{~cm}^{-1}$ ) as compared to
TABLE 3: Infrared absorption frequencies $\left(\mathrm{cm}^{-1}\right)$ of nitrate groups of lanthanide (III) complexes.

\begin{tabular}{lccccc}
\hline$\nu_{4}$ & $\nu_{1}$ & $\nu_{2}$ & $\nu_{6}$ & $\nu_{3}$ & $\nu_{5}$ \\
\hline $1546-1501$ & $1380-1287$ & $1030-1011$ & $853-812$ & $784-733$ & $701-672$ \\
\hline
\end{tabular}

monodentate nitrate anions (about $10-80 \mathrm{~cm}^{-1}$ ) complex containing ionic nitrate groups show only one band in this region assignable to $\left(v_{1}+v_{3}\right)$. The occurrence of two absorptions at $1540-1501 \mathrm{~cm}^{-1}$ and $1380-1287 \mathrm{~cm}^{-1}$ region is attributed to $v_{4}$ and $v_{1}$ modes which suggest that nitrate anions in the complexes under study are covalently bonded and are present inside the coordination sphere. If $\left(\nu_{4}-\nu_{1}\right)$ difference is taken as an approximate measure of covalence of nitrate groups, a value of $\left[\sim 200 \mathrm{~cm}^{-1}\right]$ for the complexes under study suggests a strong covalency nature of nitrate in the complexes. Lever separation rule [21] states that bidentate coordination of nitrate anion involves a greater distortion from $\mathrm{D}_{3 \mathrm{~h}}$ symmetry than unidentate coordination. In case of spectra of complexes, under study, it has been found that the separation of $\left(v_{1}+v_{4}\right)$ is good enough and is in the order $\left[\sim 200 \mathrm{~cm}^{-1}\right]$. This shows that, according to Lever separation rule, nitrate ion may be considered as covalently bonded to metal ions in bidentate fashion. Infrared absorption frequencies $\left(\mathrm{cm}^{-1}\right)$ of nitrate groups of lanthanide (III) complexes of Schiff base ligands are listed in Table 3 .

Electronic spectra were measured in EtOH, and the spectroscopic data are given in Table 2. Electronic spectral studies of lanthanide (III) metal complexes are significant and are important tool for the measurement of covalency in complexes. The line-like spectra of lanthanide (III) metal compound appearing in the UV-visible and near IR regions arise from electronic transitions within the $4 \mathrm{f}$ levels which are normal forbidden [22, 23] but may become allowed after removal of degeneracy of $4 \mathrm{f}$ orbitals by external crystal field $[24,25]$. Lanthanum (III) complexes have no significant absorption in visible region. The shift of hypersensitive bands has been utilized to calculate the nephelauxetic effect $(\beta)$, Sinha's covalency parameter $(\delta \%)$ (metal ligand covalency percentage), and the covalency factor $\left(\beta^{1 / 2}\right)$ along with 
covalency angular overlap parameter $(\eta)$; these parameters have been calculated using the following expressions [26]:

$$
\begin{aligned}
b^{1 / 2} & =\frac{1}{2}\left[(1-\beta)^{\frac{1}{2}}\right], \\
\delta \% & =\left[\frac{1-\beta}{\beta}\right] \times 100, \\
\eta & =\left(1-\beta^{1 / 2}\right) \beta^{1 / 2} .
\end{aligned}
$$

The electronic spectral studies of the lanthanide (III) metal complexes yield positive value for $(1-\beta)$ and $(\delta \%)$ which suggest that the bonding between metal and ligand is covalent in the complexes. The values of parameter of bonding $\left(\beta^{1 / 2}\right)$ and angular overlap parameter $(\eta)$ are also found to be positive indicating covalent bonding complexes.

In the spectrum of the ligands, the bands observed in the range $345-305 \mathrm{~nm}$ were assigned to $\pi-\pi^{*}$ and $\pi-\delta^{*}$ transitions. The bands in the $405-345 \mathrm{~nm}$ range may be assigned to the $\mathrm{n}-\pi^{*}$ transitions. In the electronic spectra of the $\mathrm{La}(\mathrm{III})$ complexes, the bands in the $465-405 \mathrm{~nm}$ may be assigned to $\mathrm{d}_{\pi}\left(\mathrm{La}^{\mathrm{III}}\right) \rightarrow \pi^{*}(\mathrm{~L})$ (symmetric) and $\mathrm{d}_{\pi}\left(\mathrm{La}^{\mathrm{III}}\right) \rightarrow \pi^{*}(\mathrm{~L})$ (asymmetric) MLCT transition.

The magnetic moments of the lanthanide (III) complexes are consistent with the presence of unpaired $4 \mathrm{f}$ electrons and close to the values for the free metal ions reported by Van Vleck and Frank [27]. These observations suggest that the 4 f electrons of the lanthanide (III) do not take part in bond formation in these species. The lanthanide (III) Schiff base complexes have the diamagnetic nature.

Molar conductivities were measured for freshly prepared solutions in DMF and after standing for two weeks. The conductivities increased very slightly with time in DMF for all the complexes. The coordination moieties present can not be replaced by the solvent molecules. The values of these conductances are in the range $13.2-18.5 \Omega^{-1} \mathrm{~cm}^{2} \mathrm{~mol}^{-1}$ in DMF and are in accordance with those reported for weak electrolytes in this solvent [28]. This is indicative that these complexes dissociate very slightly in this solvent.

Additional structural information can be deduced from the ${ }^{1} \mathrm{H}$ - and ${ }^{13} \mathrm{C}$-NMR spectra. The ${ }^{1} \mathrm{H}$ - and ${ }^{13} \mathrm{C}$-chemical shifts for the Schiff base ligands are given in Table 4.

The ${ }^{13} \mathrm{C}$-NMR spectra of the ligands $\mathrm{H}_{2} \mathrm{~L}^{2}$ and $\mathrm{H}_{2} \mathrm{~L}^{4}$ are shown in Figures 3(a) and 3(b).

In the ${ }^{1} \mathrm{H}$-NMR spectrum, signal belong to phenolic $\mathrm{OH}$ groups seen at between 10.2-10.4 $\left(\mathrm{HL}^{1}\right), 9.0-9.8\left(\mathrm{H}_{2} \mathrm{~L}^{2}\right)$, 10.0-11.2 $\left(\mathrm{H}_{2} \mathrm{~L}^{3}\right)$, and 10.2-10.4 $\left(\mathrm{H}_{2} \mathrm{~L}^{4}\right)$ ppm as a broad singlet. The singlets belong to azomethine group seen 8.6 $\left(\mathrm{H}_{2} \mathrm{~L}^{1}\right), 8.8\left(\mathrm{H}_{2} \mathrm{~L}^{3}\right)$, and $8.9\left(\mathrm{H}_{2} \mathrm{~L}^{4}\right)$ ppm. The multiplets belong to aromatic ring seen as a broad band at $6.2-8.0 \mathrm{ppm}$. Furthermore, the signals relative to methoxy group seen at 3.6-4.0 $\left(\mathrm{H}_{2} \mathrm{~L}^{1}\right)$, 3.8 $\left(\mathrm{H}_{2} \mathrm{~L}^{2}\right)$, and 3.8-4.0 $\left(\mathrm{H}_{2} \mathrm{~L}^{4}\right)$ as a sharp signal. In the ${ }^{13} \mathrm{C}$-NMR, the signal of carbon atom belongs to azomethine group seen at $150.0-154.0\left(\mathrm{HL}^{1}\right), 166.0-168.0$ $\left(\mathrm{HL}^{2}\right), 164.0-166.0\left(\mathrm{H}_{2} \mathrm{~L}^{3}\right)$, and $150.0-152.0\left(\mathrm{H}_{2} \mathrm{~L}^{4}\right)$. The signals related to the carbon atoms at the aromatic ring are seen at 118.0-124.0 $\left(\mathrm{H}_{2} \mathrm{~L}^{1}\right), 118.0-154.0\left(\mathrm{H}_{2} \mathrm{~L}^{2}\right), 104.0-136.0$ $\left(\mathrm{H}_{2} \mathrm{~L}^{3}\right)$, and $118.0-124.0\left(\mathrm{H}_{2} \mathrm{~L}^{4}\right)$ ppm.
The Schiff base ligands and their metal complexes were evaluated for their in vitro antibacterial activity against the B. megaterium, B. cereus, S. aureus, M. luteus, and E. faecalis (as Gram-positive bacteria) and P. aeruginosa, E. coli, and C. albicans (as Gram-negative bacteria) by agar-well diffusion. The results of antibacterial activities are given in Table 5.

The ligands and all the complexes showed prominent activity against all the bacteria B. megaterium, B. cereus, $S$. aureus, M. luteus, and E. faecalis (as Gram-positive bacteria) and $P$. aeruginosa, E. coli, and C. Albicans (as Gram-negative bacteria). All the complexes are found to be more active compared to the parent Schiff base. This is because, on chelation [29], the charge on the metal ion is reduced to a minimum increasing the lipophilicity of the complexes. This leads to the breakdown of the permeability barrier of the bacterial cell and thus retards the normal cell processes. Among the complexes formed from $\mathrm{La}(\mathrm{III})$ metal salt, $\mathrm{La}_{2}\left(\mathrm{~L}^{1}\right)\left(\mathrm{NO}_{3}\right)_{4}\left(\mathrm{H}_{2} \mathrm{O}\right)_{4}$ complex showed maximum inhibition. Also comparing the anionic species, nitrate complexes were found to inhibit bacterial growth most effectively. Antifungal studies against the fungus, E. coli, showed that both ligands and all the complexes exhibited almost hundred percent inhibitions.

The thermal studies of all the complexes were performed under nitrogen atmosphere in the temperature range of 20$1000^{\circ} \mathrm{C}$. The thermal curves of the $\mathrm{La}_{2}\left(\mathrm{~L}^{1}\right)\left(\mathrm{NO}_{3}\right)_{4}\left(\mathrm{H}_{2} \mathrm{O}\right)_{4}$ (a) and $\mathrm{La}_{2}\left(\mathrm{~L}^{4}\right)\left(\mathrm{NO}_{3}\right)_{4}\left(\mathrm{H}_{2} \mathrm{O}\right)_{4}$ (b) complexes are given in Figures $4(\mathrm{a})$ and $4(\mathrm{~b})$.

All complexes have the coordinated water molecules. As seen from Figures 4(a) and 4(b) and the figures of the other complexes, in the first step, the coordinated water molecules were eliminated at the first step in the $100-150^{\circ} \mathrm{C}$ temperature range. In the second step, the $\mathrm{NO}_{3}{ }^{-}$ion(s) coordinated to $\mathrm{La}(\mathrm{III})$ loss in the $250-310^{\circ} \mathrm{C}$ temperature range. In the last step, the organic fragments of the complexes decompose to $\mathrm{La}_{2} \mathrm{O}_{3}$ metal oxide.

4.1. Cyclic Voltammetry. DMSO and DMF solutions of the ligands and their $\mathrm{La}(\mathrm{III})$ complexes have been used to study the redox properties with the help of cyclic voltammetry. Obtained data from the electrochemical studies are given in Table 6.

The cyclic voltammograms have been recorded at a wide range of scan rates from 100 to $200 \mathrm{mVs}^{-1}$ and investigated in the potential range +2.0 to $-2.0 \mathrm{~V}$ and in $\mathrm{pH}=2-12$ with phosphate buffer. A representative voltammograms are shown in Figures 5(a) $-5(c)$.

The one-electron stoichiometry of this electron transfer process is established by comparing the current height with known one electron redox processes under identical conditions. The reversible character of the $\mathrm{La}(\mathrm{II}) \rightarrow \mathrm{La}(\mathrm{III})$ oxidation is evident from the peak-to-peak separation of 60 $70 \mathrm{mV}$ and almost equal anodic $\left(i_{\mathrm{pa}}\right)$ and cathodic peak currents $\left(i_{\mathrm{pc}}\right)$. All the complexes display irreversible ligandbased one-electron reductions on the cathodic side (Table 6). Interestingly, $\mathrm{La}\left(\mathrm{L}^{2}\right)\left(\mathrm{NO}_{3}\right)\left(\mathrm{H}_{2} \mathrm{O}\right), \mathrm{La}_{2}\left(\mathrm{~L}^{3}\right)\left(\mathrm{NO}_{3}\right)_{4}\left(\mathrm{H}_{2} \mathrm{O}\right)_{4}$, and $\mathrm{La}_{2}\left(\mathrm{~L}^{4}\right)\left(\mathrm{NO}_{3}\right)_{4}\left(\mathrm{H}_{2} \mathrm{O}\right)_{4}$ display two closely spaced MLCT bands in the electronic absorption spectra, whereas $\mathrm{La}_{2}\left(\mathrm{~L}^{1}\right)\left(\mathrm{NO}_{3}\right)_{4}\left(\mathrm{H}_{2} \mathrm{O}\right)_{4}$ displays only one MLCT band 


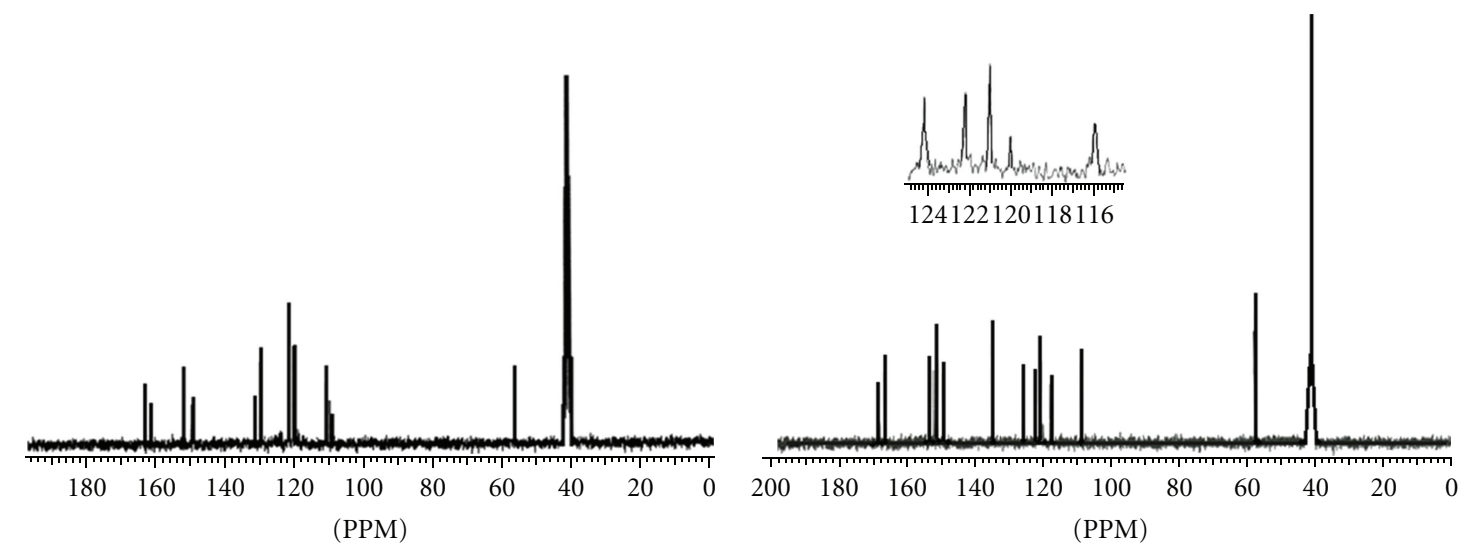

(a)

(b)

Figure 3: The ${ }^{13} \mathrm{C}$-NMR spectra of the ligands $\mathrm{H}_{2} \mathrm{~L}^{2}$ (a) and $\mathrm{H}_{2} \mathrm{~L}^{4}$ (b).

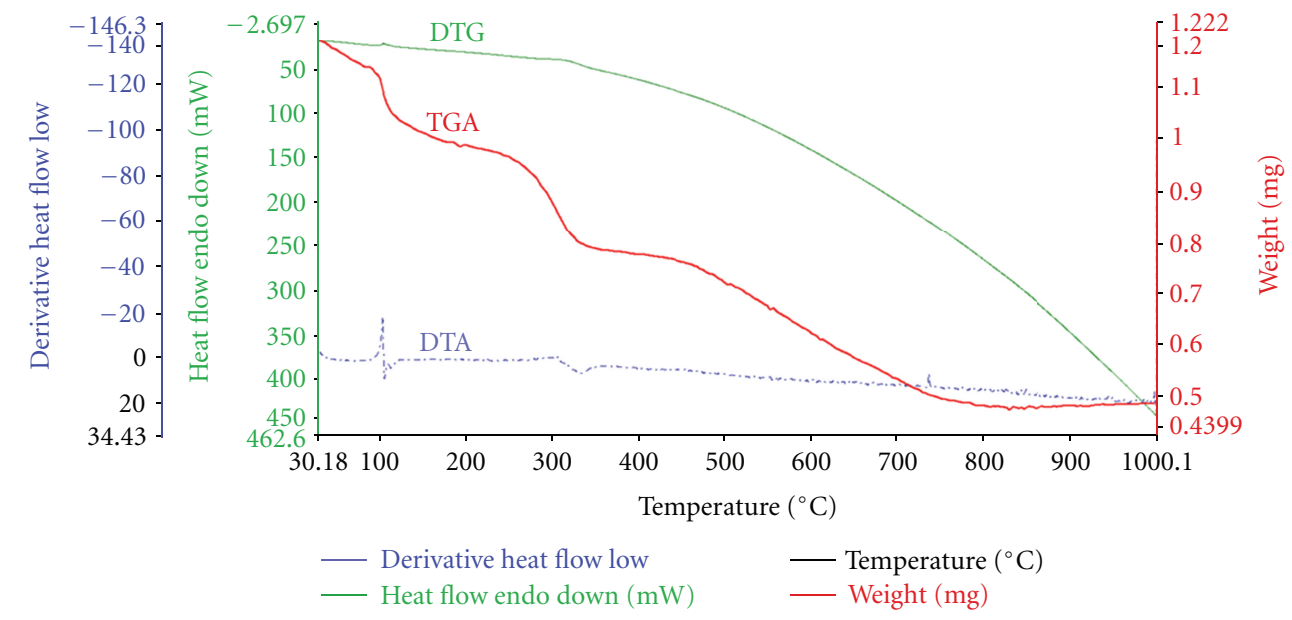

(a)

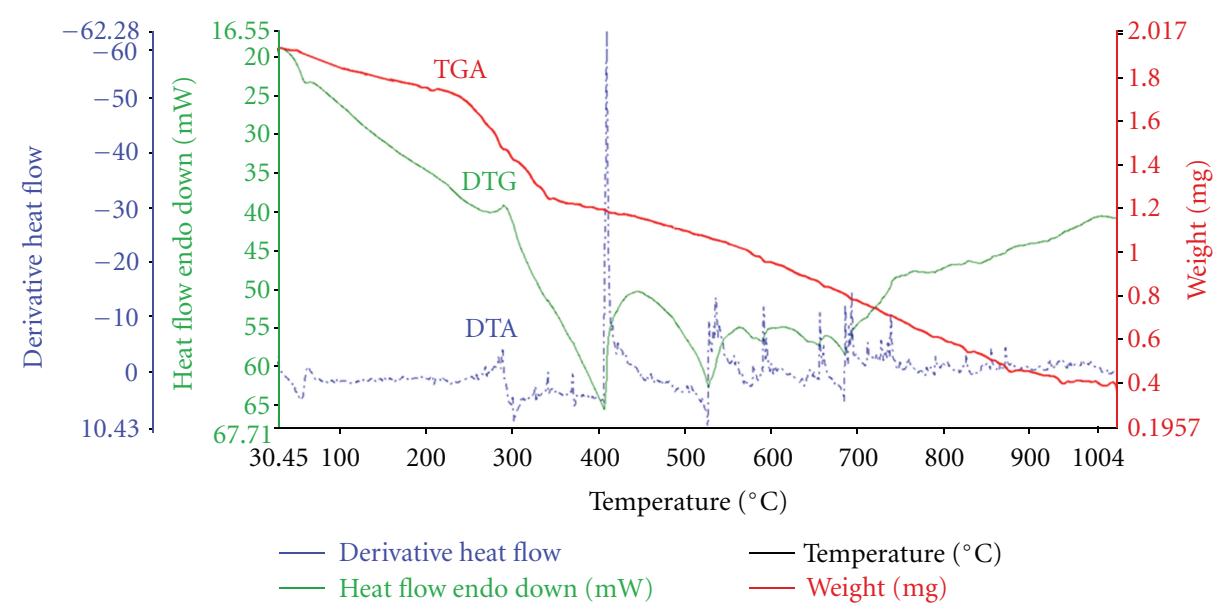

(b)

Figure 4: The thermal curves of the $\mathrm{La}_{2}\left(\mathrm{~L}^{1}\right)\left(\mathrm{NO}_{3}\right)_{4}\left(\mathrm{H}_{2} \mathrm{O}\right)_{4}$ (a) and $\mathrm{La}_{2}\left(\mathrm{~L}^{4}\right)\left(\mathrm{NO}_{3}\right)_{4}\left(\mathrm{H}_{2} \mathrm{O}\right)_{4}$ (b) complexes. 


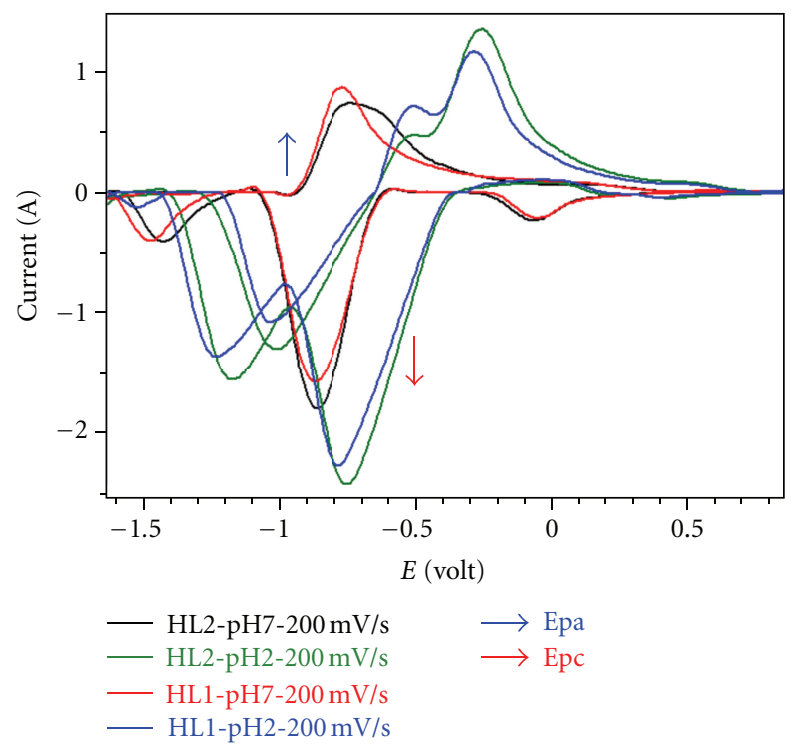

(a)

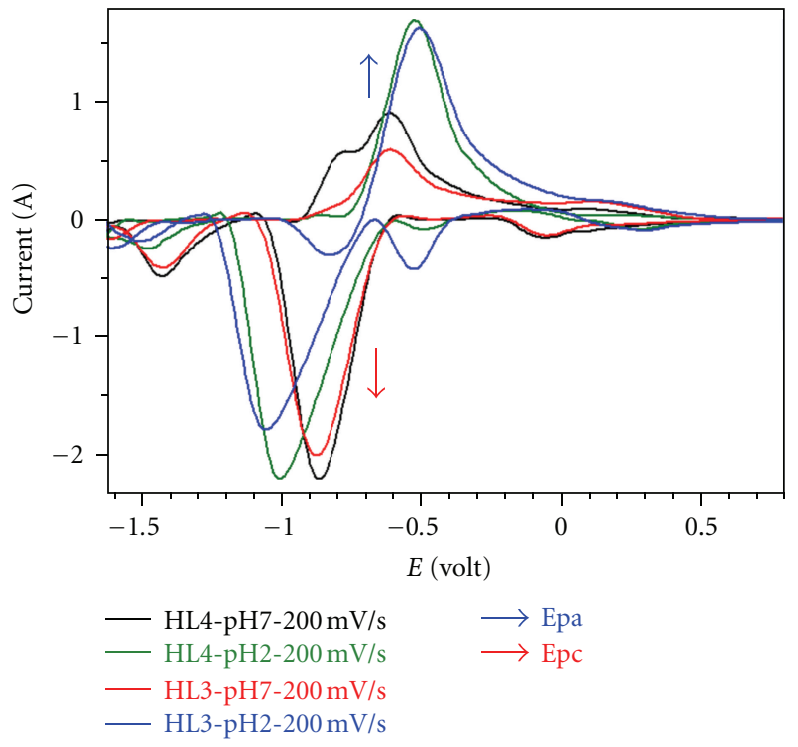

(b)

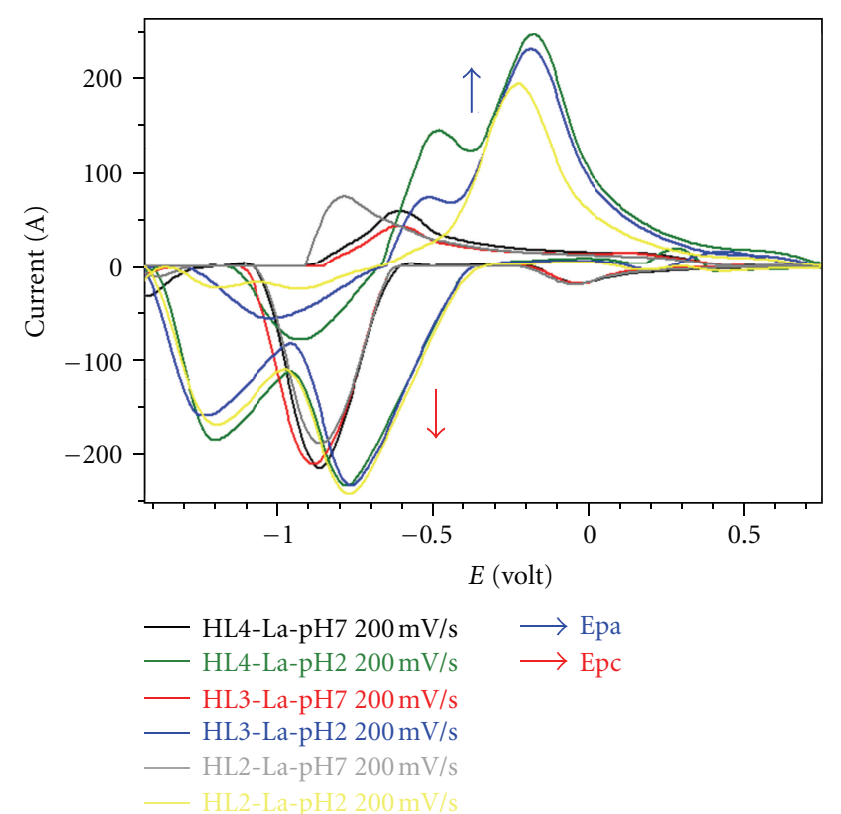

(c)

Figure 5: Cyclic voltammograms of the Schiff base ligands $\mathrm{H}_{2} \mathrm{~L}^{1}-\mathrm{H}_{2} \mathrm{~L}^{2}$ (a), $\mathrm{H}_{2} \mathrm{~L}^{1}-\mathrm{H}_{2} \mathrm{~L}^{2}$ (b), and $\mathrm{La}\left(\mathrm{L}^{2}\right)\left(\mathrm{NO}_{3}\right)\left(\mathrm{H}_{2} \mathrm{O}\right), \mathrm{La}_{2}\left(\mathrm{~L}^{3}\right)\left(\mathrm{NO}_{3}\right){ }_{4}\left(\mathrm{H}_{2} \mathrm{O}\right)_{4}$, and $\mathrm{La}_{2}\left(\mathrm{~L}^{4}\right)\left(\mathrm{NO}_{3}\right)_{4}\left(\mathrm{H}_{2} \mathrm{O}\right)_{4}$ complexes in $\mathrm{pH}=2-7$ and at the scan rate $200 \mathrm{mVs}^{-1}$.

TABle 4: The ${ }^{1} \mathrm{H}\left({ }^{13} \mathrm{C}\right)$ NMR data (as ppm) for the Schiff base ligands using DMSO- ${ }_{d 6}$ as solvent.

\begin{tabular}{lcccc}
\hline Ligands & $\mathrm{OH}$ & $\mathrm{CH}=\mathrm{N}$ & $\mathrm{Ar}$ & $\mathrm{OCH}_{3}$ \\
\hline $\mathrm{H}_{2} \mathrm{~L}^{1}$ & $10.2-10.4$ & $8.8(150.0-154.0)$ & $6.8-7.6(118.0-124.0)$ & $3.9(58.4)$ \\
$\mathrm{H}_{2} \mathrm{~L}^{2}$ & $9.0-9.2$ & $8.4(166.0-168)$ & $6.6-7.4(118.0-154.0)$ & $3.8(58.9)$ \\
$\mathrm{H}_{2} \mathrm{~L}^{3}$ & $10.0-11.2$ & $8.9(104.0-136.0)$ & $6.20-8.0(164.0-166.0)$ & - \\
$\mathrm{H}_{2} \mathrm{~L}^{4}$ & $10.2-10.4$ & $8.6(118.0-124.0)$ & $6.8-7.4(150.0-152.0)$ & $3.8(58.3)$ \\
\hline
\end{tabular}

${ }^{13} \mathrm{C}-\mathrm{NMR}$ data are given in parenthesis. 
<smiles>[R]c1ccc(/C=N/c2cc(/N=C/c3ccc([R])c([R])c3O)cc(C(=O)[O-])c2)c(O)c1[R]</smiles>

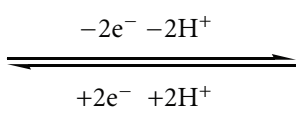<smiles>[R]C1=C([R])C(=O)/C(=C/Nc2cc(N/C=C3\C=CC([R])=C([R])C3=O)cc(C(=O)[O-])c2)C=C1</smiles><smiles>[R12][R](=O)C([Y11])([R17])OC</smiles><smiles>[R]c1ccc(/C=N/c2ccc(C([R])([R])F)c(/N=C/c3ccc([R])c([R])c3O)c2)c(O)c1[R]</smiles>

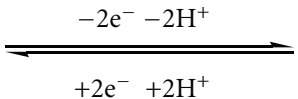<smiles>[R]C1=C([R])C(=O)/C(=C\Nc2ccc(S(=O)(=O)[O-])c(N/C=C3/C=CC([R])=C([R])C3=O)c2)C=C1</smiles>

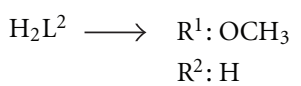

FIgURE 6: Oxidation reactions for the Schiff base ligands.

TABLe 5: Antimicrobial activity data of the Schiff base ligands and their metal complexes.

\begin{tabular}{|c|c|c|c|c|c|c|c|c|c|}
\hline Microorganisms & 1 & 2 & 3 & 4 & 5 & 6 & 7 & 8 & Control \\
\hline \multicolumn{10}{|c|}{ Gram-positive bacteria } \\
\hline B. Megaterium & 12 & 18 & 24 & 20 & 32 & 28 & 26 & 29 & - \\
\hline B. Cereus & 18 & 18 & 21 & 23 & 29 & 25 & 31 & 32 & - \\
\hline S. Aureus & 20 & 9 & 17 & 18 & 25 & 29 & 25 & 20 & - \\
\hline M. Luteus & 14 & 12 & 18 & 17 & 28 & 22 & 27 & 22 & - \\
\hline E. Faecalis & 16 & 15 & 24 & 19 & 22 & 26 & 28 & 18 & - \\
\hline \multicolumn{10}{|c|}{ Gram-negative bacteria } \\
\hline P. Aeruginosa & 29 & 13 & 18 & 15 & 27 & 28 & 26 & 32 & - \\
\hline E. Coli & 25 & 22 & 14 & 17 & 23 & 33 & 32 & 26 & - \\
\hline C. Albicans & 21 & 20 & 19 & 16 & 20 & 27 & 26 & 25 & - \\
\hline
\end{tabular}

Inhibition zone $(\mathrm{mm})$. Blanks mean not investigated. Control is the metal salt. $1: \mathrm{H}_{2} \mathrm{~L}^{1}, 2: \mathrm{H}_{2} \mathrm{~L}^{2}, 3: \mathrm{H}_{2} \mathrm{~L}^{3}, 4: \mathrm{H}_{2} \mathrm{~L}^{4}, 5: \mathrm{La}_{2}\left(\mathrm{~L}^{1}\right)\left(\mathrm{NO}_{3}\right)_{4}\left(\mathrm{H}_{2} \mathrm{O}\right)_{4}, 6$ : $\mathrm{La}\left(\mathrm{L}^{2}\right)\left(\mathrm{NO}_{3}\right)\left(\mathrm{H}_{2} \mathrm{O}\right), 7: \mathrm{La}_{2}\left(\mathrm{~L}^{3}\right)\left(\mathrm{NO}_{3}\right)_{4}\left(\mathrm{H}_{2} \mathrm{O}\right)_{4}, 8: \mathrm{La}_{2}\left(\mathrm{~L}^{4}\right)\left(\mathrm{NO}_{3}\right)_{4}\left(\mathrm{H}_{2} \mathrm{O}\right)_{4}$. 


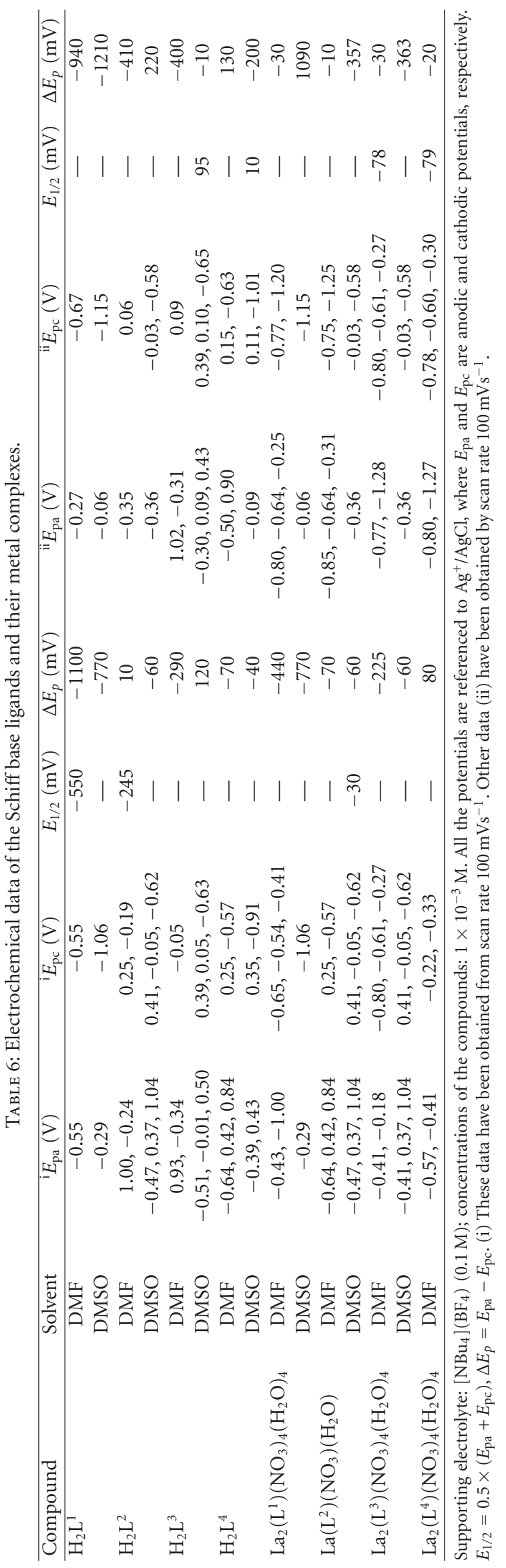


(Table 2). The MLCT transitions involve excitation of metal $\mathrm{d} \pi$ electrons to the $\pi^{*}$ orbitals of ligand which are also involved in electrochemical reductions. The MLCT band positions and the electrode potentials associated with the metal ion oxidation and ligand reduction are correlated and reflect the relative energies of the metal $\mathrm{d} \pi$ and ligand $\pi^{*}$ levels [30]. As mentioned before, the difference in the molecular structures of $\mathrm{La}_{2}\left(\mathrm{~L}^{1}\right)\left(\mathrm{NO}_{3}\right)_{4}\left(\mathrm{H}_{2} \mathrm{O}\right)_{4}, \mathrm{La}_{2}\left(\mathrm{~L}^{3}\right)\left(\mathrm{NO}_{3}\right)_{4}\left(\mathrm{H}_{2} \mathrm{O}\right)_{4}$, and $\mathrm{La}_{2}\left(\mathrm{~L}^{4}\right)\left(\mathrm{NO}_{3}\right)_{4}\left(\mathrm{H}_{2} \mathrm{O}\right)_{4}$ is the central chelate ring size formed by the imine- $\mathrm{N}$ and phenolic-O atoms of the ligands. Possibly for $\mathrm{La}\left(\mathrm{L}^{2}\right)\left(\mathrm{NO}_{3}\right)\left(\mathrm{H}_{2} \mathrm{O}\right)$ with six-membered central chelate ring, there is a small but detectable energy difference between two lowest energy acceptor levels. The observations of two MLCT bands and two ligand-based reductions for $\mathrm{La}_{2}\left(\mathrm{~L}^{3}\right)\left(\mathrm{NO}_{3}\right)_{4}\left(\mathrm{H}_{2} \mathrm{O}\right)_{4}$ and $\mathrm{La}_{2}\left(\mathrm{~L}^{4}\right)\left(\mathrm{NO}_{3}\right)_{4}\left(\mathrm{H}_{2} \mathrm{O}\right)_{4}$ and single MLCT band and single ligand-based reduction are consistent with such a situation. The $\mathrm{La}(\mathrm{II}) \rightarrow \mathrm{La}(\mathrm{III})$ oxidation potentials for $\mathrm{La}_{2}\left(\mathrm{~L}^{3}\right)\left(\mathrm{NO}_{3}\right)_{4}\left(\mathrm{H}_{2} \mathrm{O}\right)_{4}$ and $\mathrm{La}_{2}\left(\mathrm{~L}^{4}\right)\left(\mathrm{NO}_{3}\right)_{4}\left(\mathrm{H}_{2} \mathrm{O}\right)_{4}$ are within $20 \mathrm{mV}$ (Table 6). Such a situation may also be another consequence of the difference in the central chelate ring size in these complexes. The cathodic and anodic peak currents are essentially identical for all the complexes. The one-electron stoichiometry of this response is confirmed by comparing the current heights with known one-electron redox processes under identical experimental conditions [31]. The trend in the $E_{1 / 2}$ values reflects the influence of the electronic nature of the substituents $(\mathrm{R})$ at the para position of the O-coordinating deprotonated carboxy and sulphoxy functionality present in the ligands. For the most electronreleasing substituent $\left(\mathrm{R}=\mathrm{OH}, \mathrm{OCH}_{3}\right)$, the oxidation of the metal ion occurs at the lowest potential, and, for the most electron withdrawing substituent $\left(\mathrm{R}=\mathrm{COOH}, \mathrm{SO}_{3} \mathrm{H}\right)$, it occurs at the highest potential.

The influence of $\mathrm{pH}$ on the cyclic voltammograms at a glassy carbon electrode in $1 \times 10^{-3} \mathrm{M}$ ligands and their complexes solutions, $v=200 \mathrm{mVs}^{-1}$, is shown in Figures 5(a)-5(c). It is observed that the profile of the $I \times E$ curves is the same in the $\mathrm{pH}$ range studied, indicating that the electrooxidation of the ligands follows the same reaction mechanism. However, with the increase of $\mathrm{pH}$, the anodic and cathodic peak potentials are shifted toward less positive values. The shift of $E_{\mathrm{pa}}$ to less positive values indicates an increase in the nucleophilicity of the organic compound [32] and that its antioxidant activity is thermodynamically favored with the $\mathrm{pH}$ increase.

It is important to note that the dependence of $E_{\mathrm{pa}}$ with $\mathrm{pH}$ is attenuated when the $\mathrm{pH}$ changes from 7.4 to 8.5. This behavior can be explained by the increase of the concentration of the ligands in solution. In the oxidation of the ligands $\mathrm{H}_{2} \mathrm{~L}^{1}, \mathrm{H}_{2} \mathrm{~L}^{2}$ and $\mathrm{H}_{2} \mathrm{~L}^{4}$, only two protons are involved (Figure 6), while, in the oxidation of the ligand $\mathrm{H}_{2} \mathrm{~L}^{3}$, four protons are involved. In the solutions of $\mathrm{pH}$ higher than 8.5, the reduction peak was not observed (data not shown), which indicates that the products of oxidation of the Schiff base ligands and their metal complexes became unstable and an irreversible homogeneous chemical reaction occurs. For this reason, we limited our studies to the $\mathrm{pH}$ range 2.0-8.5.

\section{Conclusion}

In summary, we have synthesized new lanthanum complexes from the Schiff base ligands with $\mathrm{La}$ (III) and characterized by conventional methods. The structures of the ligands are drawn in Figure 1. Various attempts such as crystallization using mixtures of solvents, low-temperature crystallization were unsuccessful to obtain a single crystal suitable for Xray crystallography. Promising results are obtained when screened for antibacterial and antifungal activities. The effect of $\mathrm{pH}$ in the complex solutions was investigated and determined that affect the redox properties of the ligands and their metal complexes.

\section{References}

[1] M. Tümer, "Polydentate schiff-base ligands and their Cd(II) and $\mathrm{Cu}(\mathrm{II})$ metal complexes: synthesis, characterization, biological activity and electrochemical properties," Journal of Coordination Chemistry, vol. 60, no. 19, pp. 2051-2065, 2007.

[2] M. Tümer, H. Köksal, and S. Serin, "Synthesis, characterization and thermal investigation of some metal complexes derived from new schiff base ligands," Synthesis and Reactivity in Inorganic and Metal-Organic Chemistry, vol. 28, no. 8, pp. 1393-1404, 1998.

[3] M. Tümer, H. Köksal, M. K. Şener, and S. Serin, "Antimicrobial activity studies of the binuclear metal complexes derived from tridentate Schiff base ligands," Transition Metal Chemistry, vol. 24, no. 4, pp. 414-420, 1999.

[4] J. W. Pyrz, A. I. Roe, L. J. Stern, and J. R. Que, "Model studies of iron-tyrosinate proteins," Journal of the American Chemical Society, vol. 107, no. 3, pp. 614-620, 1985.

[5] M. Tümer, B. Erdoğan, H. Köksal, S. Serin, and M. Y. Nutku, "Preparation, spectroscopic characterisation and thermal analyses studies of the $\mathrm{Cu}(\mathrm{II}), \mathrm{Pd}(\mathrm{II})$ and $\mathrm{Vo}(\mathrm{IV})$ complexes of some Schiff base ligands," Synthesis and Reactivity in Inorganic and Metal-Organic Chemistry, vol. 28, no. 4, pp. 529-542, 1998.

[6] J. Chakraborty and R. N. Patel, "Copper-, cobalt- and zinc(II) complexes with monofunctional bidentate Schiff base and monodentate neutral ligands," Journal of the Indian Chemical Society, vol. 73, no. 4-5, pp. 191-193, 1996.

[7] J. E. Huneey, E. A. Keitar, and R. L. Keiter, Inorganic Chemistry: Principles of Structure and Reactivity, pp. 57-85, Rearsen Education, Singapore, 2002.

[8] D. K. Koppikar, P. V. Sivapulliah, L. Ramakrishnan, and S. Soundararjan, "Complexes of the lanthanides with neutral oxygen donor ligands," Structure and Bonding, vol. 34, pp. 135-213, 1978.

[9] C. Mealli and E. C. Lingafelter, "The X-ray crystal structure of a low-spin pseudo-octahedral complex of iron(II)," Journal of the Chemical Society D, no. 14, p. 885, 1970.

[10] M. J. Upadhyay, P. K. Bhattacharya, P. A. Ganeshpure, and S. Satish, "Epoxidation of alkenes with iodosylbenzene using mono-and binuclear Ru(III)-Schiff base complex catalysts," Journal of Molecular Catalysis, vol. 73, no. 3, pp. 277-285, 1992.

[11] T. Mukaiyama and T. Yamada, "Recent advances in aerobic oxygenation," Bulletin of the Chemical Society of Japan, vol. 68, no. 1, pp. 17-35, 1995.

[12] D. Riley, M. Stern, J. Ebner, D. H. R. Barton, A. E. Martell, and D. T. Sawyer, The Activation of Dioxygen and Homogeneous Catalytic Oxidation, Plenum Press, New York, NY, USA, 1993. 
[13] R. A. Sheldon and J. K. Kochi, Metal Catalysed Oxidations of Organic Compounds, Academic Press, New York, NY, USA, 1981.

[14] B. Meunier, "Metalloporphyrins as versatile catalysts for oxidation reactions and oxidative DNA cleavage," Chemical Reviews, vol. 92, no. 6, pp. 1411-1456, 1992.

[15] M. J. Carter, D. P. Rillema, and F. Basolo, "Oxygen carrier and redox properties of some neutral cobalt chelates. Axial and inplane ligand effects," Journal of the American Chemical Society, vol. 96, no. 2, pp. 392-400, 1974.

[16] D. F. Averill and R. F. Broman, "Substituted salen and baen tetradentate Schiff-base ligands. Synthesis, characterization, and electrochemistry of cobalt(III) complexes," Inorganic Chemistry, vol. 17, no. 12, pp. 3389-3394, 1978.

[17] G. S. Patterson and R. H. Holm, "Structural and electronic effects on the polarographic half wave potentials of copper (II) chelate complexes," Bioinorganic Chemistry, vol. 4, no. 3, pp. 257-275, 1975.

[18] C. H. Collins, P. M. Lyne, and J. M. Grange, Microbiological Methods, Butterworths, Oxford, UK, 6th edition, 1989.

[19] M. Dolaz, M. Tümer, and M. Diğrak, "Synthesis, characterization and stability constants of polynuclear metal complexes," Transition Metal Chemistry, vol. 29, no. 5, pp. 528-536, 2004.

[20] E. C. Alyea, A. Malek, and A. E. Vougioukas, "Lanthanide complexes of potentially heptadentate Schiff base ligands," Canadian Journal of Chemistry, vol. 60, no. 5, pp. 667-372, 1982.

[21] A. B. P. Lever, E. Mantiovani, and B. S. Ramaswamy, "Infrared combination frequencies in coordination complexes containing Nitrate groups in various coordination environments," Canadian Journal of Chemistry, vol. 49, no. 11, pp. 1957-1964, 1971.

[22] N. K. Dutt and S. Rahut, "Chemistry of lanthanonsXXV. The formation constants of the ethyl thioacetoacetato complexes of rare earths," Journal of Inorganic and Nuclear Chemistry, vol. 32, pp. 2105-2112, 1970.

[23] K. Arora, M. Sharma, and K. P. Sharma, "Studies of some lanthanide(III) nitrate complexes of schiff base ligands," $E$ Journal of Chemistry, vol. 6, pp. 201-210, 2009.

[24] K. I. Kugel and D. I. Khomskii, "Crystal structure and magnetic properties of substances with orbital degeneracy," Soviet Physics - JETP, vol. 37, no. 4, pp. 725-730, 1973.

[25] S. B. Pirkers, A. V. Lapitskaya, T. G. Vaistub, T. A. Baranova, A. K. Chulkevich, and A. M. Fainleib, "Studies of some lanthanide(III) nitrate complexes of schiff base ligands," Zhurnal Neorganicheskoi Khimii, vol. 29, pp. 369-379, 1984.

[26] S. P. Tondon and P. C. Mehta, "Bonding inferred from study of nephelauxetic effect in neodymium complexes," Journal of Chemical Physics, vol. 52, pp. 4314-4325, 1970.

[27] J. H. Van Vleck and A. Frank, "The effect of second order Zeeman terms on magnetic susceptibilities in the rare earth and iron groups," Physical Review, vol. 34, no. 11, pp. 14941496, 1929.

[28] W. J. Geary, "The use of conductivity measurements in organic solvents for the characterisation of coordination compounds," Coordination Chemistry Reviews, vol. 7, no. 1, pp. 81-122, 1971.

[29] A. T. Çolak, F. Çolak, O. Z. Yesilel, D. Akduman, F. Yilmaz, and M. Tümer, "Supramolecular cobalt(II)-pyridine2,5-dicarboxylate complexes with isonicotinamide, 2-amino3-methylpyridine and 2-amino-6-methylpyridine: ayntheses, crystal structures, spectroscopic, thermal and antimicrobial activity studies," Inorganica Chimica Acta, vol. 363, no. 10, pp. 2149-2162, 2010.
[30] B. K. Ghosh and A. Chakravorty, "Electrochemical studies of ruthenium compounds part I. Ligand oxidation levels," Coordination Chemistry Reviews, vol. 95, no. 2, pp. 239-294, 1989.

[31] S. Pal and S. Pal, "Ruthenium(II) complexes containing $\mathrm{RuN}_{4} \mathrm{O}_{2}$ spheres assembled via pyridine-imine-amide coordination. Syntheses, structures, properties and protonation behaviour of coordinated amide," Journal of the Chemical Society, Dalton Transactions, no. 9, pp. 2102-2108, 2002.

[32] D. T. Sawyer, A. Sobkowiak, and J. L. Roberts Jr., Electrochemistry for Chemists, John Wiley \& Sons, New York, NY, USA, 2nd edition, 1995. 


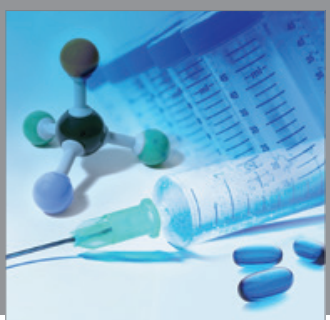

International Journal of

Medicinal Chemistry

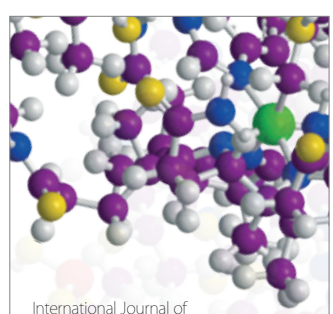

Carbohydrate Chemistry

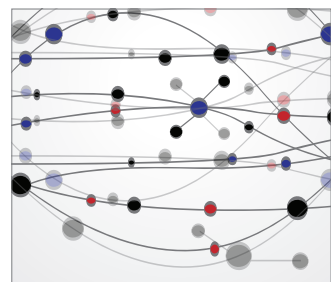

The Scientific World Journal
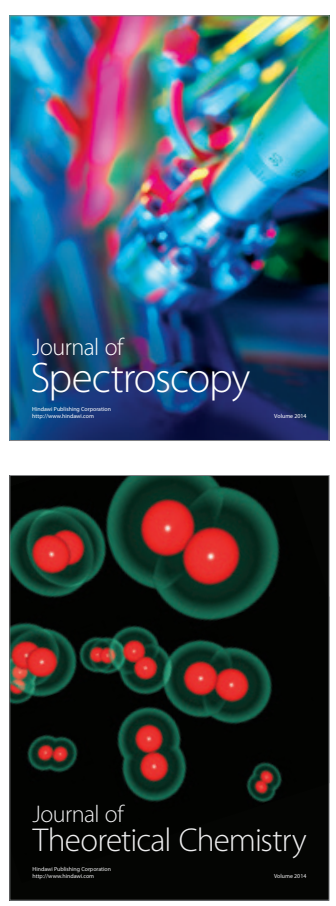
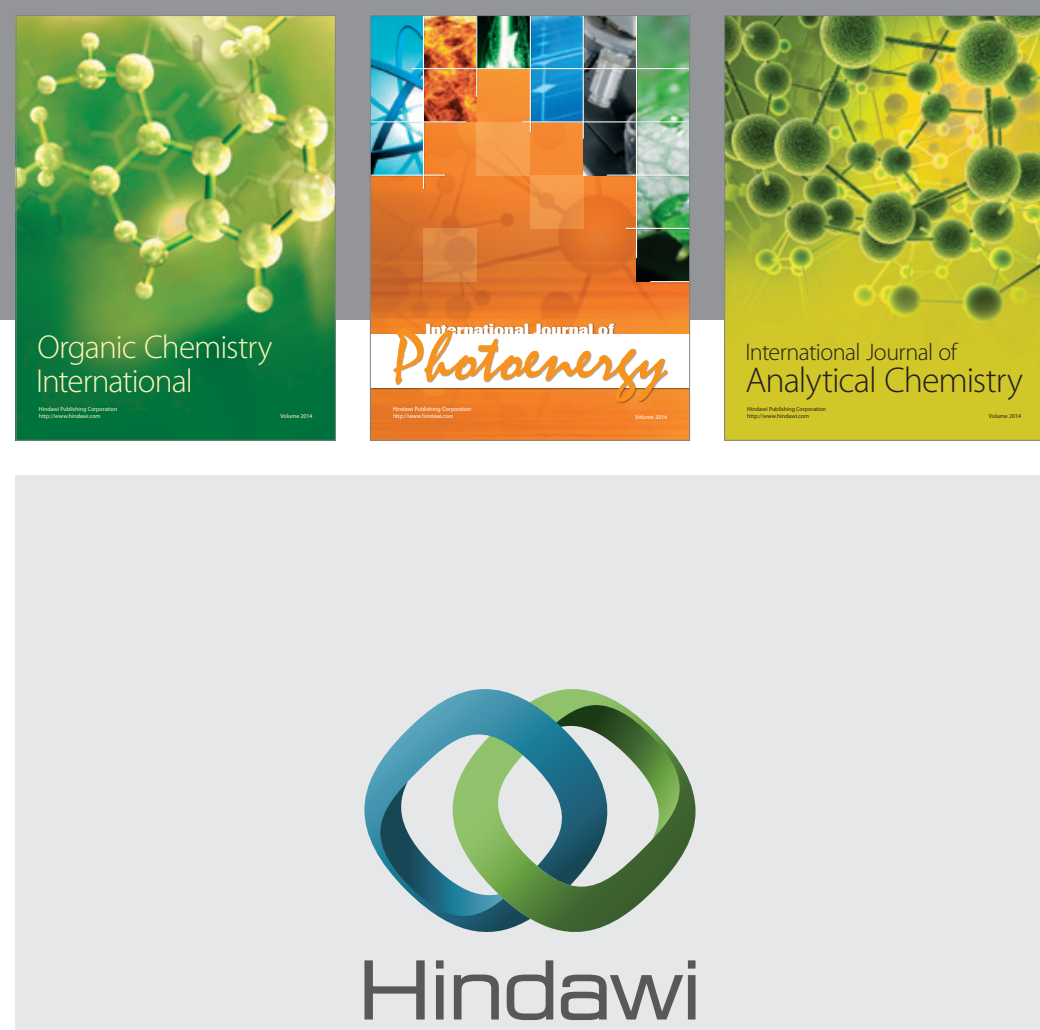

Submit your manuscripts at

http://www.hindawi.com
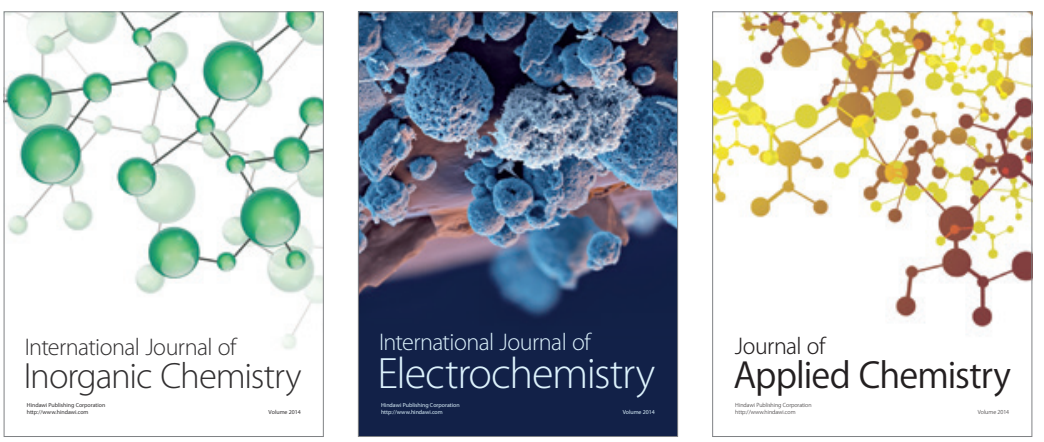

Journal of

Applied Chemistry
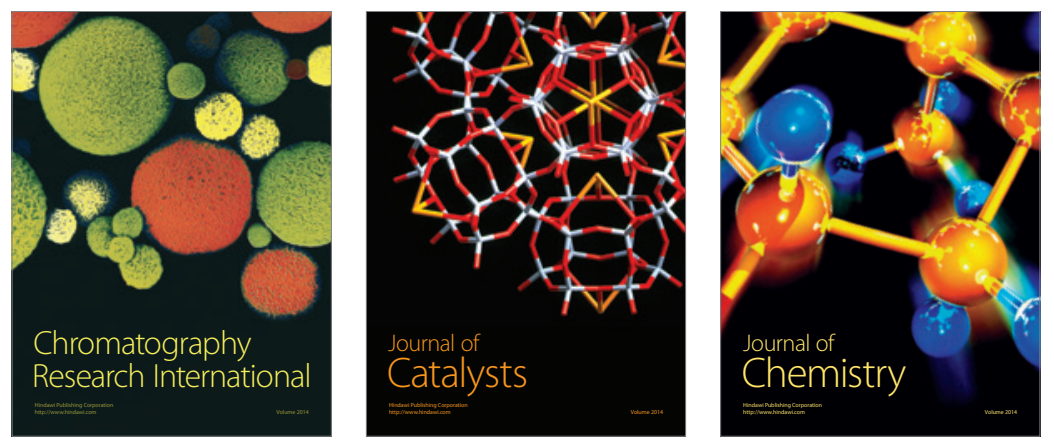
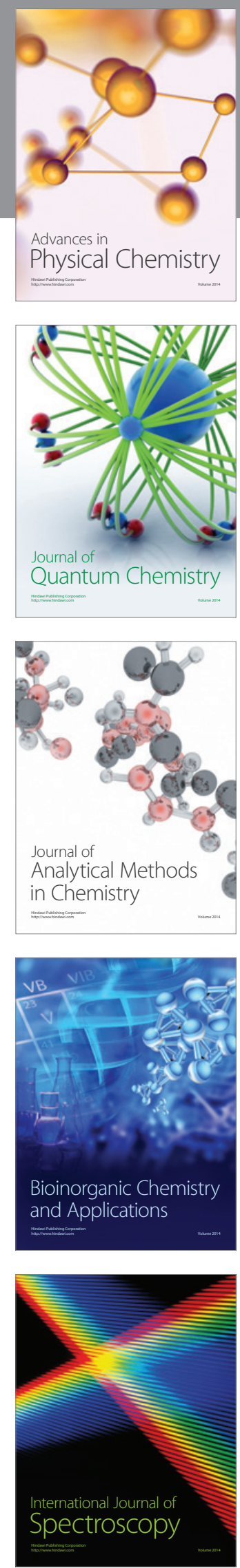